\title{
Performance Evaluation of Five Row Animal Drawn Multi Crop Planter
}

\author{
N.K. Dhruwe ${ }^{1 *}$, V.M. Victor ${ }^{1}$, Amit Namdeo ${ }^{1}$ and P.K. Nishad ${ }^{2}$ \\ ${ }^{1}$ Department of Farm Machinery and Power Engineering, FAE, IGKV, Raipur, \\ Chhattisgarh, India \\ ${ }^{2}$ ICAR-Central Institute of Agricultural Engineering, Bhopal, Madhya Pradesh, India \\ *Corresponding author
}

\section{A B S T R A C T}

\section{Keywords \\ Planter, Draught animals, Draft required, Precise seed metering system \\ Article Info \\ Accepted: \\ 15 January 2018 \\ Available Online: \\ 10 February 2018}

A five row animal drawn multi-crop planter was developed at the SV College of Agricultural Engineering and Technology, IGKV, Raipur and it was evaluated for its performance by conducting lab tests and field trials. The tests comprised of the determination of average weight of seeds discharged, percentage damage of seeds, calibration of a planter, field performance studies and average depth of placement of seeds. The mean field capacity and field efficiency was found to be $0.22 \mathrm{ha} / \mathrm{h}$ and $79.78 \%$ respectively. The speed of operation was $1.75 \mathrm{~km} / \mathrm{h}$ and the average draft required to pull the multi-crop planter was $43.21 \mathrm{kgf}$. The average depth of seed placement was observed to be $40 \mathrm{~mm}$. The average plant population was found to be $17,16,14,14$ and 12 plants within rows of $2 \mathrm{~m}$ length for wheat, chick pea, green gram, pigeon pea and ground nut, respectively. The cost of operation was found to be Rs 321.78 per ha.

\section{Introduction}

Agricultural work in India is carried out by using manual, animal and mechanical power sources. Animal power contribution in the total power used in agriculture is about 33 per cent (Mishra, 1986). 84 million draught animals are used for crop production and transportation purposes (Cartman, 1994).

India has a large population of draught animals and bullocks are main draught animal in the country followed by he-buffaloes. Generally draught animals are used for tillage, seeding, interculture operation and transportation work. Bullock is one of the cheapest sources of draught power for all kinds of agricultural operations in villages of Chhattisgarh because large agricultural machines like tractor and power tiller are neither feasible nor economically viable due to poor financial condition of farmers and fragmented land holdings. Inns (1998) reported that the draught $(\mathrm{H})$ of a cultivation implement varied directly with the effective vertical force (V) acting on it and inversely with the tangent of the angle (a) at which it pulled. The relationship could be expressed in the form of tillage implement draught equation: $\mathrm{H}=\mathrm{V} / \mathrm{tan}$ a. Devanani (1991) reported the work of Mason Vough (1947) who found that the bullocks developed draught equivalent to $1 / 5$ to $1 / 6$ of their body weight and maximum draft which the bullocks 
could exert varied from 49.5 to $60.5 \%$ of the body weight.

Due to fragmented and small land holdings and variable farmer typology, it is neither affordable nor advisable to purchase many machines for the planting of different crops by the same farmer. The multi-crop planter can plant different crops with variable seed size, seed rate, depth, spacing etc., effectively and economically. The multi-crop planters have precise seed metering system using cup feed type seed metering devices roller with variable grove number and size for different seed size and spacing for various crops.

\section{Materials and Methods}

The study was conducted in the year 2016 at Swami Vivekananda College of Agricultural Engineering and Technology, IGKV, Raipur. The planter was tested both in the laboratory and field. The planter was tested as per BIS test code IS 6316: 1993for wheat, chick pea, green gram, pigeon pea and ground nut. The planter is shown in (Fig. 1). The field was prepared before evaluation. Instruments like measuring tape, stop watch, polythene bag, square metallic frame and weight balance were used to evaluate the planter. Cost of operation of planter was calculated and was compared with different practices. The procedure for evaluation of planter is given in the following sections.

\section{Evaluation of the planter}

Parameter such as field capacity, field efficiency, seed rate, Speed of operation, Power requirement and cost of operation of the planter was evaluated.

\section{Field capacity}

Theoretical field capacity was measured as per following formula. (Bainer et al., 1987),
Theoretical Field capacity, $(\mathrm{ha} / \mathrm{h})=\frac{\mathrm{w} \times \mathrm{S}}{10}$

Where,

$\mathrm{W}=$ Effective width of implement, $\mathrm{m}$; and

$\mathrm{S}=$ Speed of operation, $\mathrm{km} / \mathrm{h}$.

\section{Actual field capacity}

Actual field capacity was measured by taking an area of $45 \times 25$ square meter i.e. 0.112 ha and measuring the time in actual field condition. It includes turning loss, filling time and break down time also. There was continuously operated in the field for 0.112 ha to assess its actual coverage. The time required for complete application was recorded and effective field capacity was calculated.

Actual Field capacity $\left(\right.$ ha/h) $=\frac{\text { A }}{\mathrm{T}}(2)$

Where,

$\mathrm{A}=$ Actual area covered, ha

$\mathrm{T}=$ Time required to cover the area, $\mathrm{h}$

\section{Field efficiency}

From the actual and theoretical field capacity, the field efficiency was calculated (Bainer et al., 1987),

Field efficiency, $(\%)=\frac{\text { AFC }}{\text { TFC }} \times 100$

Where,

$\mathrm{FE}=$ Field efficiency $(\%)$

$\mathrm{AFC}=$ Actual field capacity $(\mathrm{ha} / \mathrm{h}) ;$ and

$\mathrm{TFC}=$ Theoretical field capacity $(\mathrm{ha} / \mathrm{h})$. 


\section{Operating speed}

The speed of operation of planter was determined in test plots by putting two marks $30 \mathrm{~m}$ apart (A \& B). The time was recorded with the help of stop watch to travel the distance of $30 \mathrm{~m}$. The speed of operation was calculated in $\mathrm{km} / \mathrm{h}$ as given below

$S=\frac{72}{T}$

Where,

$\mathrm{S}=$ Speed of operation, $\mathrm{km} / \mathrm{h}$

$\mathrm{T}=$ time needed to cover $30 \mathrm{~m}$ distance, $\mathrm{sec}$

\section{Power requirement}

Calculation of power is needed to determine the efficient use of animal power. A man can produce power equal to $0.1 \mathrm{hp}$. It was the power required to operate the machine pair of bullock with an average pulling force and speed. It was calculated by using the formula.

power, $(\mathrm{hp})=\frac{\text { pulling forcs }(\mathrm{kg}) \times \operatorname{speed}(\mathrm{m} / \mathrm{s})}{75} \ldots$

Operational cost of five row animal drawn multi crop planter

The cost of operation for developed planter was calculated by following procedure. The operating cost includes fixed and variable cost.

\section{Fixed Cost}

Fixed cost is the total cost of depreciation, interest on investment and shelter. Straightline method was used for calculating the depreciation of the machine. a) Annual depreciation

$$
\mathrm{D}=\frac{C-S}{\mathrm{~L}}
$$

Where,

$\mathrm{D}=$ Depreciation/year

$\mathrm{C}=$ Initial cost

$\mathrm{S}=$ Scrap value $=C / 10$, and

$\mathrm{L}=$ Life of machine in years.

Interest investment at 12 percent per annum

$\mathrm{I}=\frac{C+S}{2} \times \mathrm{i}$

Total over head cost Rs = Annual depreciation + Interest investment per year. Hence, total cost (over head) per hour

\section{Variable cost}

Repair and maintenance cost at 10 percent of initial cost

Wage of operator in Rs for working 8 hours therefore

Hiring charges of bullock in Rs for working of 4 hours

Total Cost of Operation

Total cost of operation is the sum of fixed cost and variable cost of the planter. Total cost, TC $=$ Fixed cost + Variable cost

\section{Results and Discussion}

\section{Field efficiency}

The theoretical field capacity was determined as $0.27 \mathrm{ha} / \mathrm{h}$, whereas the actual field capacity of planter was found to be $0.22 \mathrm{ha} / \mathrm{h}$. From the actual and theoretical field capacity the field efficiency of the light weight animal drawn multi crop planter was found to be $79.78 \%$ (Table 2). 
Table.1 Seed rate of the different crops

\begin{tabular}{|c|c|c|c|c|c|c|}
\hline Crop & $\begin{array}{c}\text { Recommende } \\
\text { d seed rate } \\
\text { (kg/ha) }\end{array}$ & $\begin{array}{c}\text { Row to row } \\
\text { distance } \\
(\mathrm{cm})\end{array}$ & $\begin{array}{c}\text { Plant to } \\
\text { plant } \\
\text { distance } \\
\text { (cm) }\end{array}$ & $\begin{array}{c}\text { Opening } \\
\text { exposure } \\
\text { scale }\end{array}$ & $\begin{array}{c}\text { Seed } \\
\text { metering } \\
\text { roller }\end{array}$ & $\begin{array}{c}\text { Seed rate } \\
\text { achieved } \\
\text { (kg/ha) }\end{array}$ \\
\hline Wheat & $100-125$ & 20 & $8-20$ & 4 & 5 & 115.68 \\
\hline Chick pea & $75-80$ & 30 & $10-12$ & 5 & 3 & 81.84 \\
\hline $\begin{array}{c}\text { Green } \\
\text { gram }\end{array}$ & $15-20$ & 30 & $8-10$ & 7 & 4 & 17.92 \\
\hline Pigeon Pea & $18-20$ & $60-90$ & $15-20$ & 2 & 2 & 19.85 \\
\hline $\begin{array}{c}\text { Ground } \\
\text { nut }\end{array}$ & 100 & $30-45$ & $15-20$ & 2 & 2 & 98.58 \\
\hline Fertilizer & 100 & -- & - & 6 & 3 & 103 \\
\hline
\end{tabular}

Table.2 Field efficiency of the five row animal drawn multi crop planter

\begin{tabular}{|c|c|c|c|c|}
\hline Draft (kgf) & $\begin{array}{c}\text { Speed of } \\
\text { operation (kmph) }\end{array}$ & $\begin{array}{c}\text { Depth } \\
(\mathbf{m m})\end{array}$ & $\begin{array}{c}\text { Power } \\
(\mathrm{kW})\end{array}$ & $\begin{array}{c}\text { Field efficiency } \\
(\%)\end{array}$ \\
\hline 43.21 & 1.75 & $40-45$ & 0.22 & 79.78 \\
\hline
\end{tabular}

Fig.1 Isometric view of developed five row animal drawn multi crop planter

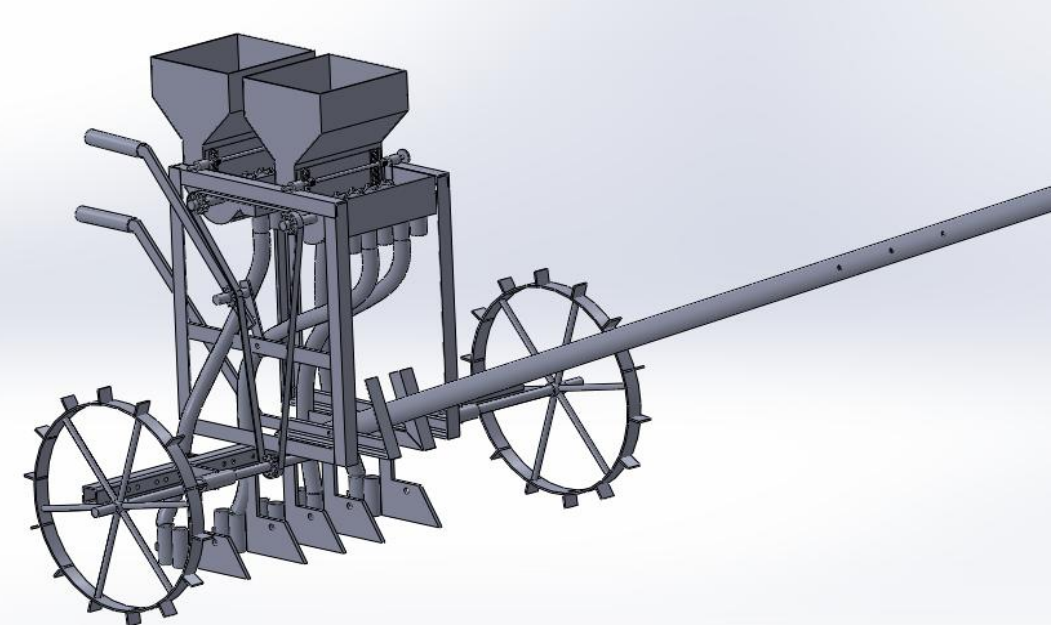

\section{Seed rate}

The seed rate for different crop showed in Table 1. Maximum seed rate was found to be $115.68 \mathrm{~kg} / \mathrm{ha}$ for wheat and minimum 17.92 $\mathrm{kg} / \mathrm{ha}$ for green gram, respectively.

\section{Measurement of draught}

The spring dynamometer was hitched between the yoke and the planter beam during the operation. The pulling force varied from minimum 52.63 to maximum $54.83 \mathrm{~kg}$ at $36.68^{\circ}$ angle of inclination. The draught 
accordingly computed varied from $42.20 \mathrm{kgf}$ $(413 \mathrm{~N})$ to $43.97 \mathrm{kgf}(431.34 \mathrm{~N})$.

\section{Power requirement}

The average power required for 5-row animal drawn multi crop planter was found to be 0.20 $\mathrm{kW}(0.27 \mathrm{hp})$ which may be operated by a pair of bullocks with average output of $0.5 \mathrm{hp}$.

\section{Speed of operation}

The speed of operation was found to vary from 1.74 to $1.77 \mathrm{~km} / \mathrm{h}$. The average speed of operation of developed planter for sowing of selected seeds was found to be $1.75 \mathrm{~km} / \mathrm{h}$, respectively, for a distance of $30 \mathrm{~m}$.

\section{Cost estimation and cost of operation}

The cost of operation of the developed machine was found to be Rs $70.79 / \mathrm{h}$ and Rs 321.78/ha.

The study concluded that the seed rate of the planter was less when compared to traditional method of sowing. The cost of operation was found to be Rs 70.79/h and Rs 321.78/ha for all the crops. The cost of sowing with the planter was less when compared to traditional methods. This provides flexibility for use of these planters for direct drilling of different crops with precise rate and spacing using the same planter which does not exist in flutted roller metering drills. Hence, the same multicrop planter can be used for planting different crops by simply changing the roller. The planter has the provision of drilling both seed and fertilizer in one go. The planter is useful for small and marginal farmers who cannot afford large machinery and for fields where large machinery is not suitable.

\section{References}

Bainer R., Kepner, R.A. and Barger, E.L. 1987 Principles of Farm Machinery. C.S.B. Publishers and distributor, New Delhi.

Cartman (1994). National conference on policies and programmes for modernisation of draught animal power system. New Delhi, 4 - 5 March.

Devnani, R. S. 1991. Agricultural machinery design and data handbook: RNAM ESCAP.

Inns, F. M. 1998. High-lift harness and light weight plough; an efficient low draught ploughing system. Landwords. 53(1):12-16.

Mishra, T.N. (1986) "Energy analysis of major crops of Tarai region of Uttar Pradesh" Unpublish Ph.D. Thesis G.B. Pant University of Agricultural and Technology Pantnagar.

\section{How to cite this article:}

Dhruwe N. K., V. M. Victor, Amit Namdeo and Nishad P. K. 2018. Performance Evaluation of Five Row Animal Drawn Multi Crop Planter. Int.J.Curr.Microbiol.App.Sci. 7(02): 1547-1551. doi: https://doi.org/10.20546/ijcmas.2018.702.186 